eCommons@AKU

THE AGA KHAN UNIVERSITY

Medical College, Pakistan

Department of Biological \& Biomedical Sciences

January 2015

\title{
How Pakistan's media spreads the message about reproductive and sexual health
}

Syed H. Abidi

Aga Khan University, syed.abidi@aku.edu

Muhammad Raees

Aga Khan University

Syed Ali

NazarbayevUniversity, syed.ali@nu.edu.kz

Follow this and additional works at: https://ecommons.aku.edu/pakistan_fhs_mc_bbs

Part of the Biochemistry Commons

\section{Recommended Citation}

Abidi, S. H., Raees, M., Ali, S. (2015). How Pakistan's media spreads the message about reproductive and sexual health. BMJ, 350, h1309.

Available at: https://ecommons.aku.edu/pakistan_fhs_mc_bbs/510 


\title{
How Pakistan's media spreads the message about reproductive and sexual health
}

\author{
Liberalising influences in the past 20 years have led to a media policy that may have helped improve \\ reproductive and sexual health in the country, say Syed H Abidi, Muhammad Raees, and Syed \\ Ali
}

\section{Syed H Abidi assistant professor ${ }^{1}$, Muhammad Raees medical student ${ }^{2}$, Syed Ali associate professor ${ }^{3}$}

${ }^{1}$ Biological and Biomedical Sciences, Aga Khan University, Karachi 74800, Pakistan; ${ }^{2}$ Medical College, Aga Khan University, Karachi 74800, Pakistan; ${ }^{3}$ Department of Biomedical Sciences, Nazarbayev School of Medicine, Nazarbayev University, Astana, Kazakhstan

When Muhammad Zia-ul-Haq, then president of Pakistan, died on 17 August 1988, it informally pronounced the end of an era widely regarded in Pakistan as one of religious fundamentalism, repression, and blatant media censorship.

Then in the early 2000s Pervez Musharraf's government implemented policies that emphasised moderation in religious practice, ideological tolerance, and collective socioeconomic emancipation. ${ }^{12}$ This government also supported a free media, which led to the establishment of more than 100 cable television channels and multitudes of newspapers, magazines, and radio channels. $^{3}$

Television documentaries that highlight socially sensitive topics may increase public awareness and attract the attention of policy makers. In 2013 three documentaries by Sanjog Pakistan, a non-profit organisation for children's rights, tackled child trafficking and prostitution in the country. ${ }^{46}$ Other documentaries have portrayed the lives and problems of female sex workers and transgender people. ${ }^{56}$

\section{Public awareness of sexual health}

The government also allowed foreign channels to air documentaries pertaining to sex and sexuality. On primetime television it has become common to see transgender people as both fictional characters and programme hosts. In subsequent years the media broadened the public's comfort zone to a point where families felt less embarrassed when a documentary about sex, or a message promoting reproductive health, was broadcast in the early evening.

Nowadays the internet raises public awareness of everyday sexual matters that were previously considered highly sensitive. Interactive educational websites and blogs now offer accurate information and online support on matters pertaining to sexual and reproductive health. ${ }^{7-11}$
Newspapers and magazines also regularly feature articles on transgenderism, reproductive health, family planning, contraceptives, sexually transmitted infections, and sexual health. ${ }^{9-12}$ Raised public awareness has encouraged tolerance of diverse sexual practices and behaviours-for example, the Supreme Court of Pakistan in 2009 recognised transgenderism as a "third gender." 13

In the past few years it has become possible to publicise products such as condoms, contraceptives, and sanitary towels in the media. Once cryptic commercials about female toiletries now depict adolescent girls, the target consumer, dancing, singing, and participating in athletics. ${ }^{14}$

Discussion of contraceptives was once impossible in public forums. The marketing of condoms for spacing births began in 1986. But advertising condoms in the mass media was not allowed, and promotional campaigns occurred only in shops. ${ }^{15}$ In the late 90s, under more liberal leaderships, condom commercials became acceptable on national television; however, use of the word "condom" was not allowed until the mid-2000s. Revised media policies allow advertisements for condoms and sanitary pads to run in print periodicals as long as they are not on the cover. ${ }^{15}$

\section{Is the message getting through?}

Data from the Pakistan Demographic and Health Surveys show that $44 \%$ of 5184 women in 2006-07 were exposed to family planning messages on radio and television, compared with $21 \%$ of 8041 in $1990-91 .^{16}$

Several studies have tried to gauge public attitudes toward sexual and reproductive health in Pakistan. One found that of 288 women visiting a local reproductive healthcare centre, 224, 256, and 260 thought that television, billboards, and print media, 
respectively, had influenced them to use modern contraceptive methods. ${ }^{17}$ Three studies—which surveyed 617 married men, 1606 married men, and 150 married couples-indicated that seeing condom advertisements was associated with greater belief in effectiveness, less embarrassment when buying condoms, more discussions about family planning, and more use of contraceptives. ${ }^{15} 1819$

In a 2002 study that evaluated knowledge of sexually transmitted infections among a rural community, through in-depth interviews of healthcare workers and focus groups, most community members had basic awareness about the causes of AIDS and hepatitis and their risk factors. ${ }^{20}$ The study participants identified the mass media as their main source of information. Similarly $63 \%$ of 400 interns and nurses interviewed in 2010 about prevention of cervical cancer said that mass media was effective for disseminating knowledge. ${ }^{21}$ Another report identified cable television and the internet as key sources of information on sexual health for adolescent women. ${ }^{22}$ Liberalisation of the media may also have contributed to Pakistan's steady decline in total fertility rate, from $4.34 \%$ in 2000 to $2.86 \%$ in $2014 .^{23}{ }^{24}$ However, changes in attitudes seem not to have been universal. For example, most Pakistanis live in rural areas and may be less aware of sexual health than urban dwellers. ${ }^{25}$ A study of 1532 patients visiting sexual health clinics in Faisalabad from 2006 to 2009 found the prevalence of syphilis, gonorrhoea, genital herpes, chlamydia, and chancroid to be $29.5 \%, 13 \%, 3.2 \%$, $4.7 \%$, and $1.3 \%$, respectively, comparable with rates observed in other cities of Pakistan. ${ }^{26}$ Of the 1532 patients, 54\% (819) did not know about condoms, and 45\% (695) knew about condoms but had not used them.

Prevalence of HIV as high as $11 \%$ has been found among men who have sex with men in Pakistan. ${ }^{27}$ A study of self reported sexual behaviour among 1431 men who have sex with men and 1415 transgender sex workers found consistent condom use in only $31-41 \% .^{28}$ A study of female sex workers in Lahore reported prevalence of up to $1.2 \%, 7.9 \%, 10 \%, 14.9 \%$, and $11.2 \%$ for HIV, syphilis, gonorrhoea, chlamydia, and trichomoniasis, respectively. Less than $6 \%$ of infected participants reported always using a condom. ${ }^{29}$

\section{What next?}

Campaigns are needed to raise awareness of sexual health matters in rural and high risk populations. These populations are largely undereducated, so visual media may be more appropriate than printed media. Campaigns should be tailored to the specific television channels most popular in these communities, and media coverage should be widened where it is lacking. Peers from high risk groups, such as men who have sex with men and sex workers, should be engaged to spread the messages of timely vaccination and safe sex practices.

Commercial sex workers use mobile phones for networking and soliciting clients. ${ }^{28}$ This mode of communication might help in awareness campaigns - health centres could send text and voice messages about sexually transmitted infections, reproductive health, and so on. Indeed, a sexual health text messaging service, Sexinfo, developed by the San Francisco Department of Public Health, has been effective in raising awareness of sexually transmitted infections among adolescents. ${ }^{30}$

Over the past two decades Pakistan's media has softened the boundaries of sexual taboos in the country. This has probably led to more tolerance for diverse sexual behaviour, acceptance of sexual liberation, and a more sensible attitude towards reproductive health.

Competing interests: We have read and understood BMJ policy on declaration of interests and have no relevant interests to declare. This work was supported by the Higher Education Commission, Pakistan, grant 20-2267

Provenance and peer review: Not commissioned; not externally peer reviewed.

1 Musharraf P. A plea for enlightened moderation. Washington Post 2004 Jun 1. www. washingtonpost.com/wp-dyn/articles/A5081-2004May31.html.

Atta-Ur-Rahman, Nasim A. Time for 'enlightened moderation.' Nature 2004;432:273-4.

3 lqbal Z. Media and Musharraf: a marriage of convenience. Eur Sci J 2012;8.

4 Black Box Sounds. Documentaries on child rights. Sanjog Pakistan. www.blackboxsounds. com/documentaries-on-child-rights-for-sanjog-pakistan-2/.

5 Anwerzada M. Female sex workers in Pakistan. www.youtube.com/watch?v=O5tv82dMjio.

6 Chinoy SO. Transgenders: Pakistan's open secret. 2011. http://sharmeenobaidfilms.com 2011/12/transgenders/.

7 Sexual and Reproductive Health Matters. www.srhmatters.org/.

8 The Express Tribune Blogs. Stories about sex education. http://blogs.tribune.com.pk/tag/ sex-education/.

9 Husain S. Adolescents in Pakistan have little knowledge of sexual health: JPMA. News International 2012 Dec 28. www.thenews.com.pk/Todays-News-4-151047-Adolescentsin-Pakistan-have-little-knowledge-of-sexual-health-JPMA.

10 Adolescents, parents demand more awareness about reproductive health rights. Daily Times 2013 Mar 16. http://archives.dailytimes.com.pk/lahore/16-Mar-2013/adolescentsparents-demand-more-awareness-about-reproductive-health-rights.

11 Experts to discuss family planning, reproductive health issues. Pakistan News Service 2013 Feb 11. http://paktribune.com/news/Experts-to-discuss-family-planning-reproductivehealth-issues-257309.html.

12 llyas F. Transgenders need to be accepted into mainstream. Dawn 2012 Jan 15. www. dawn.com/news/688421/transgenders-need-to-be-accepted-into-mainstream.

13 Shahzad K. Pakistan's transgender political candidates stake claim in national vote. Huffington Post 2013 Apr 18. http://investorshub.advfn.com/boards/read_msg.aspx? message_id $=87637110$.

14 Wahedna D'Arcy. Always Ultra Pakistan. www.youtube.com/watch?v=iLVDhS1KniY.

15 Agha S, Meekers D. Impact of an advertising campaign on condom use in urban Pakistan. Stud Fam Plann 2011;41:277-90.

16 Carton TW, Agha S. Changes in contraceptive use and method mix in Pakistan: 1990-91 to 2006-07. Health Policy Plan 2011;27:166-74.

17 Qazi H, Hashmi A, Raza S, Soomro J, Ghauri A. Contraceptive methods and factors associated with modern contraceptive in use. J Family Reprod Health 2010;4:41-6.

18 Agha S, Beaudoin CE. Assessing a thematic condom advertising campaign on condom use in urban Pakistan. J Health Commun 2012;17:601-23.

19 Sultan K, Younus S. Mass media and family planning: understanding the effects of television in innovation-decision process of health communication in district Peshawar. Khyber Med Uni J 2010;2:58-63.

20 Afsar HA, Mahmood MA, Barney N, Ali S, Kadir MM, Bilgrami M. Community knowledge, attitude and practices regarding sexually transmitted infections in a rural district of Pakistan. $J$ Pak Med Assoc 2002;52:21-4.

21 Ali SF, Ayub S, Manzoor NF, et al. Knowledge and awareness about cervical cancer and its prevention amongst interns and nursing staff in tertiary care hospitals in Karachi, Pakistan. PLoS One 2010:5:e11059.

22 Ali TS, All PA, Waheed H, Memon AA. Understanding of puberty and related health problems among female adolescents in Karachi, Pakistan. J Pak Med Assoc 2006;56:68-72.

23 World Bank. Fertility decline in Pakistan 1980-2006. 2010. http://siteresources.worldbank. org/INTPRH/Resources/376374-1278599377733/Pakistan62810PRINT.pdf.

24 Nasir JA, Akhtar M, Tahir MH. Reproductivity and age-specific fertility rates in Pakistan after 1981. Pak J Statist 2009;25:251-63.

25 Raheel H, White F, Kadir MM, Fatmi Z. Knowledge and beliefs of adolescents regarding sexually transmitted infections and HIV/AIDS in a rural district in Pakistan. J Pak Med Assoc 2007;57:8-11.

26 Maan MA, Hussain F, Iqbal J, Akhtar SJ. Sexually transmitted infections in Pakistan. Ann Saudi Med 2011;31:263-9.

27 Khanani MR, Somani M, Khan S, Naseeb S, Ali SH. Prevalence of single, double, and triple infections of HIV, HCV and HBV among the MSM community in Pakistan. $J$ Infect 2010;61:507-9.

28 Thompson LH, Salim M, Baloch CR, et al. Heterogeneity of characteristics, structure, and dynamics of male and hijra sex workers in selected cities of Pakistan. Sex Transm Infect 2013;89(Suppl 02):ii43-47.

29 Khan MS, Unemo M, Zaman S, Lundborg CS. HIV, STI prevalence and risk behaviours among women selling sex in Lahore, Pakistan. BMC Infect Dis 2011;11:119.

30 Ybarra ML, Bull SS. Current trends in internet- and cell phone-based HIV prevention and intervention programs. Curr HIV/AIDS Rep 2007;4:201-7.

Cite this as: BMJ 2015;350:h1309

(c) BMJ Publishing Group Ltd 2015 